\title{
ARTICLE \\ Parasite community of a temporal notothen fish from intertidal rocky pools in south-central Chile: Is it similar to other fish from the same habitat?
}

Comunidad de parásitos de un pez nototénido temporal del intermareal rocoso del centro-sur de Chile: ¿es similar a la de otros peces del mismo hábitat?

\section{Gabriela Muñoz $^{*}$, Francisco Vildoso ${ }^{1}$ and Mario George-Nascimento ${ }^{2}$}

${ }^{1}$ Facultad de Ciencias del Mar y de Recursos Naturales, Universidad de Valparaíso, Avenida Borgoño 16344, Viña del Mar, Chile.*gabriela.munoz@uv.cl

${ }^{2}$ Departamento de Ecología, Facultad de Ciencias, Universidad Católica de la Santísima Concepción, Alonso de Ribera 2850, Concepción, Chile

\begin{abstract}
Resumen.- Los peces nototénidos (Nototheniidae) han sido registrados en las costas de Sudamérica, desde los $35^{\circ} \mathrm{S}$ hasta el extremo austral. Poco se sabe de su biología y de relaciones interespecíficas, incluyendo sus parásitos. En este estudio se analizó la parasitofauna de una especie de Notothenia juvenil, recolectada del intermareal rocoso de Lebu, centro-sur de Chile $\left(36^{\circ} \mathrm{S}\right)$, y se comparó con las comunidades de parásitos de otras 9 especies de peces del mismo hábitat. Notothenia sp. mostró la mayor diversidad de parásitos en comparación a otras especies de peces (21 vs 1-9 taxa parasitarios). La composición parasitaria fue diferente entre las especies de peces analizadas, de 0 a $33 \%$ de similitud. Notothenia sp. presentó la mayor semejanza solo con Calliclinus geniguttatus (27\%). Los parásitos con mayor abundancia y prevalencia en Notothenia sp. fueron el copépodo Caligus cf. cheilodactyli, larvas de Tetraphyllidea, nematodos anisákidos, y varias especies de acantocéfalos, siendo estos parásitos típicos de peces de las zonas submareales y demersales. Se concluye que los ejemplares de Notothenia sp. estaban parasitados cuando alcanzaron la zona intermareal. Solo unas pocas especies parásitas generalistas pudieron ser adquiridas por Notothenia sp. durante su corta estadía en este ambiente, tales como el copépodo Holobomolochus chilensis y el digeneo Lecithaster macrocotyle. Muchos peces nototénidos son de aguas antárticas y subantárticas, siendo posible que Notothenia sp. provenga de otros hábitats, submareal y demersal, pero también del extremo austral Sudamericano. En este estudio, Notothenia sp. no pudo ser identificada a nivel específico debido a las diferencias entre resultados morfológicos y genéticos.
\end{abstract}

Palabra clave: Comunidades de parásitos, similitud parasitaria, Notothenia, pozas intermareales, costa chilena

Abstract.- Notothen fishes (Nototheniidae) have been recorded on the coasts of South America, from $35^{\circ} \mathrm{S}$ to southern. Little is known about the biology of intertidal notothen fishes or their relationships with other species, including parasites. Here, we analyzed the parasitic fauna of a species of Notothenia collected from the rocky intertidal of Lebu, south-central Chile $\left(36^{\circ} \mathrm{S}\right)$ and compared the parasite community of this host with other 9 fish species commonly found in intertidal rocky pools. Among the tested species, Notothenia sp. had the highest parasite richness (21 parasitic taxa vs. 1 to 9 parasitic taxa). The composition of parasite species was different among fishes, with similarity indices between 0 and $33 \%$. The parasite composition of Notothenia sp. was most similar to Calliclinus geniguttatus (27\%). The most abundant and prevalent parasites found in Notothenia sp. were the copepod Caligus cf. cheilodactyli, Tetraphyllidea larvae, anisakid nematodes, and several acanthocephalan species, which are typical of other fish from the subtidal and bento-demersal zones. Therefore, we conclude that the juveniles of Notothenia sp. were a few months old and had their parasites when reaching the intertidal zone, acquired some generalist parasites during their stay in this habitat, such as Holobomolochus chilensis and Lecithaster macrocotyle. Most notothen fishes are from Antarctic and Sub-Antarctic waters, therefore, it is possible that this fish came from another habitat but also from the austral region of South America. Notothenia sp. could not be specifically identified because of different results between morphological and genetic analyses.

Key words: Parasite communities, parasitic similarity, Notothenia, intertidal pools, Chilean coast 


\section{INTRODUCTION}

The great species diversity in intertidal zones has attracted scientific interest for many years, which has been focused on establishing and describing the interspecific relationships that are formed there. In Chile, several studies have dealt with the relations of competition or coexistence among species (e.g., Shinen \& Navarrete 2010, Aguilera et al. 2013), between predators and prey (e.g., Quijada \& Cáceres 2000, Berrios \& Vargas 2004) and relationships between parasites and hosts (e.g., Muñoz \& Cortés 2009, Soto et al. 2016). All these studies agree that intertidal systems are diverse and highly complex in their organization.

The intertidal zone has environmental characteristics that favor the recruitment of juvenile stages of many invertebrate and vertebrate species, which use this area as a temporary refuge, settlement, and for a definitive life. Thus, resident fish species, mostly benthic organisms, live permanently in the intertidal zone. This group is represented by the families Blenniidae, Clinidae, Trypteriigidae, and Labrisomidae (Quijada \& Cáceres 2000, Muñoz \& Delorme 2011). On the other hand, temporal fish live in that zone for a short period and can be associated with a certain ontogenetic stage (juveniles or adults), including Clupeidae, Kyphosidae, and Nototheniidae species (Pequeño \& Lamilla 1995). Both resident and temporal fish groups are present along the Chilean coast, although the abundances of the species vary considerably among geographical areas (Navarrete et al. 2014).

Although resident and temporal fish share the habitat (same rocky pools), and food (several mollusks and crustaceans), and often have comparable body sizes, the composition of their parasite communities can differ because of different dwell times in the intertidal zone and arrival at different development stages (Muñoz \& Delorme 2011). Temporal juvenile fish have presented different parasitic compositions even when they come from nearby localities (Muñoz et al. 2001, 2002), which indicates that their parasite communities are highly variable; whereas the resident fish have a composition of parasite communities that are less variable among nearby localities (Flores \& George-Nascimento 2009, Muñoz-Muga \& Muñoz 2010) and over time, although there are certain seasonal differences (Díaz \& George-Nascimento 2002, Muñoz \& Delorme 2011).

The Sub-Antarctic region, according to oceanographic characteristics, extents from central-south of Chile and
Argentina $\left(38-40^{\circ} \mathrm{S}\right)$, ending in the waters located south of Cape Horn in the Drake Strake (55-56 $\left.{ }^{\circ} \mathrm{S}\right)$. In this region, Nototheniidae is a predominant fish family (Norman 1937), which includes benthic or pelagic species that live in cold waters at the southern hemisphere (Eastman 1991). Most of notothen records are from $45^{\circ} \mathrm{S}$ to south (Reyes \& Hüne 2012). There are two species found in rocky intertidal pools at the central-southern coast of Chile, in northern distribution limit; Notothenia microlepidota in Mehuín (39 22'S) (Small 1976) and Notothenia cf. angustata close to Concepción City [Maule $37^{\circ} 0^{\prime} \mathrm{S} ; 7^{\circ} 14^{\prime} \mathrm{W}$, and Isla Santa María $37^{\circ} \mathrm{S} ; 73^{\circ} 30^{\prime} \mathrm{W}$ (Muñoz et al. 2001), as well as a record of a Notothenia sp. at Burca $36^{\circ} 32^{\prime} \mathrm{S} ; 7^{\circ} 55^{\prime} \mathrm{W}$ (Quijada \& Cáceres 2000)]. These species have been found during the austral summer as juveniles, with body lengths between 8 and $13 \mathrm{~cm}$ (Small 1976, Quijada \& Cáceres 2000, Muñoz et al. 2001).

Little is known about intertidal notothen fishes; there is only some dietary information (Pequeño 1976, Quijada \& Cáceres 2000, Muñoz et al. 2001) and one parasitological record for $N$. cf. angustata (Muñoz et al. 2001). According to the few reports addressing notothen species from central-south of Chile described above, these species are unlikely to be recruited from the intertidal zone. Consequently, it is worth asking how much of the parasitic fauna of a notothen species is brought from another habitat and if parasitic species can be acquired during their intertidal stay. The objectives of this study were: 1) to identify a notothen species obtained from Lebu, a close locality from Concepción, central-southern Chile; 2) to describe the parasite community of that fish species; and 3 ) to compare this with those parasites of other intertidal fish species from the central-southern zone of Chile.

\section{Materials ANd Methods}

\section{FiSH COLLECTION AND IDENTIFICATION}

Between March and May 2014-2015, 388 fish were collected in the area of Lebu, from $36^{\circ} 45^{\prime} 3.971^{\prime \prime S}$ $73^{\circ} 11^{\prime} 2.738^{\prime \prime} \mathrm{W}$ to $36^{\circ} 47^{\prime} 4.265^{\prime \prime S}-73^{\circ} 12^{\prime} 21.532^{\prime \prime} \mathrm{W}$, located approximately $145 \mathrm{~km}$ south of Concepción City (36²9’29.485"S -73³'41.965"W), south-central Chile.

The fish were captured in rocky intertidal pools during low tides, using hand nets and with $1 \%$ benzocaine anesthetic solution (BZ-20 ${ }^{\circledR}$, Veterquímica, Chile). All of the captured specimens were placed in individual plastic bags, labelled, and transferred to the laboratory, where they were frozen $\left(\right.$ at $-20{ }^{\circ} \mathrm{C}$ ) for further analysis. 
At the time of fish dissection, each specimen was identified according to Williams (1990), Stepien (1993) and Reyes \& Hüne (2012). In the case of Nototheniidae, the taxonomic identification of species has been controversial, and with few taxonomic keys available and updated (e.g., Fischer \& Hureau 1985). Therefore, prior to the dissection of the specimens, a meristic analysis was made to compare it with other notothen species, based on the information obtained from several bibliographic sources (e.g., Pequeño 1976, 1984; Fischer \& Hureau 1985, Reyes \& Hüne 2012, McMillan et al. 2014) and the website $<$ www.fishbase.com $>$ (Froese \& Pauly 2017). The distribution of the hypural bones was also observed according to the descriptions given by Fischer \& Hureau (1985). The total length and the wet weight were recorded for each fish specimen.

The meristic comparisons between Nototheniidae species were carried out with cluster analysis, using the simple union similarity index, and the distance between the fish species by the Euclidean method (De Vienne et al. 2011) carried out in the STATISTICA 7.0 program. Several species had a few meristic measures. Therefore, 2 clusters were carried out. The first analysis considered 7 measurements (spines and dorsal fin rays, anal fin rays, pectoral and pelvic fin rays, number of upper and lower lateral line scales) in 10 notothen species. The second analysis considered 3 meristic variables (spines and dorsal fin rays, anal fin rays) of 30 notothen species. In both analyses we include a juvenile fish determined as Notothenia cf. angustata by Muñoz et al. (2001) that was from an area close to the present study. The maximum and minimum values of each meristic measurement were considered as separate variables. Thus, the first working matrix contained 13 variables in 10 species, and the second 6 variables in 30 species.

Genomic DNA was extracted from single specimens of the notothen fish to determine their taxonomic identity. Tissue samples (muscles) were stored in $96 \%$ ethanol and DNA was extracted by E.Z.N.A. ${ }^{\circledR}$ Tissue DNA kit (Omega Bio-Tek, Norcross, GA, USA). The barcode region of the cytochrome oxidase I (COI) was the gene chosen to obtain an approximation at the genus or species level of the fish. The primers employed for PCR amplification were LCO (GGT CAA CAA ATC ATA AAG ATA TTG G) and HCO (TAAACT TCA GGG TGA CCAAAAAAT CA) for the COI gene (Folmer et al. 1994).
Each PCR assay had a final volume of $25 \mu$ land included $0.125 \mu \mathrm{l}$ of Taq polymerase, $2.5 \mu \mathrm{l}$ of $10 \times$ PCR buffer, $0.5 \mu \mathrm{l}$ of dNTPs (10 mM), $4 \mu \mathrm{l}$ of $\mathrm{MgCl}_{2}(25 \mathrm{mM}), 1 \mu \mathrm{l}$ of primers (according to the gene analysed), $1.5 \mu \mathrm{l}$ of BSA (BioLabs) (19 $\mathrm{mg} \mathrm{mL}^{-1}$ ), $3 \mu \mathrm{l}$ of concentrated DNA (10 to $200 \mathrm{ng}$ of DNA) and $11.375 \mu 1$ of water. The thermocycling conditions for amplification were: an initial denaturation step at $95^{\circ} \mathrm{C}$ ( $5 \mathrm{~min}$ ), followed by 40 cycles at $95^{\circ} \mathrm{C}(45 \mathrm{~s}), 50^{\circ} \mathrm{C}(45 \mathrm{~s})$ and $72{ }^{\circ} \mathrm{C}(1 \mathrm{~min})$, and a final extension step at $72{ }^{\circ} \mathrm{C}(10$ min) (Folmer et al. 1994).

The PCR products were visualised on $1 \%$ agarose gel via electrophoresis and purified using the E.Z.N.A. ( $\mathrm{Bel}$ Extraction kit (Omega Bio-Tek, Norcross, GA, USA). The PCR products for each specimen were sequenced using an automated capillary electrophoresis sequencer (ABI 3730XL, Macrogen, Inc., Seoul, Korea) ${ }^{1}$. The sequences were blasted to other data available in GenBank, using the IgBLAST 1.8.0 tool program (National Center for Biotechnology Information, Bethesda, MD) ${ }^{2}$.

\section{Parasitological analysis}

Ectoparasites were sought under a stereoscopic microscope observing the skin, fins and gills of the fish. Subsequently, fish were dissected for the collection of endoparasites from the coelomic cavity, digestive tract and musculature. For detailed observation under a magnifying glass, each organ was sieved using a $250 \mu \mathrm{m}$ mesh. Both ecto- and endoparasites were stored, labeled, and preserved in $70 \%$ ethanol in Eppendorf tubes.

When possible, parasites were identified at the lowest taxonomic level, considering bibliographic references indicated in Soto et al. (2016) and adding others, such as Petrochenco (1971), Zdzitowiecki (1997), Amin et al. (2011), and Laskowski \& Zdzitowiecki (2017). Abundance and prevalence (sensu Bush et al. 1997) were calculated for each species of parasite in each host sample. We also calculate the total prevalence as the percentage of a fish sample parasitized with any parasite species.

\footnotetext{
${ }^{1}<$ http://www.macrogen.com>

${ }^{2}<$ https://www.ncbi.nlm.nih.gov/>
} 
Parasite infracommunity abundance and richness were calculated for each host and averaged by fish species sample. Then, these descriptors were compared among fish species using the Kruskal-Wallis test. The total prevalence of parasite community per fish species was also calculated and then compared between fish species through contingency tables. Both the total prevalence and the average abundance and infracommunity parasite richness were correlated with the average body weight of the fish, using Pearson's correlation analysis. A significance level of 0.05 was used for all statistical analyzes.

The similarity of parasite composition among fish species was calculated using the Jaccard similarity coefficient (Brower \& Zar 1977) based on presenceabsence of parasite taxa in the fish. Parasite taxa that were present in one fish specimen were not considered for this analysis. Subsequently, to test whether groups of fish were distinguished according to their parasitic fauna, a Nonmetric-Multidimensional Scaling (NMDS) analysis was carried out together with an Analysis of
Similarities (ANOSIM) (Clarke \& Warwick 1991, Chapman \& Underwood 1999), using Past 3.2 software (Øyvind Hammer, Natural History Museum, University of Oslo) ${ }^{3}$.

\section{Results}

\section{TAXONOMIC IDENTIFICATION OF A NOTOTHEN FISH}

The distribution of the hypural bones of notothen specimens is in accordance to the genus Notothenia (Fischer \& Hureau 1985). The morphological comparison, when considering the matrix of 13 variables and 10 species (Fig. 1A), shows that all of the meristic ranges of Notothenia sp. were similar to Notothenia cf. angustata (juveniles in Muñoz et al. 2001) and N. angustata (adults in Fischer \& Hureau 1985). The analysis with the matrix of 6 variables and 30 species also showed that specimens of the present study were within a small group composed of N. microlepidota, Notothenia cf. angustata, N. angustata, and Paranotothenia magellanica (Fig. 1B, Table 1). This group was distant from all of the other notothen species considered in this analysis.

Table 1. Meristic morphology of the notothenioid species most similar to the fish species collected for the present study (Notothenia sp.). $\mathbf{N}$. coriiceps is also included due to its similitude in the sequence of the $\mathrm{COI}$ gene to Notothenia sp. / Morfología merística de las especies nototénidas más parecidas a la especie recolectada en el presente estudio (Notothenia sp.). Se incluye también a $N$. coriiceps por ser cercana en la secuencia genética del gen $\mathrm{COI}$ a Notothenia sp.

\begin{tabular}{|c|c|c|c|c|c|c|c|c|c|}
\hline Scientific name & $\begin{array}{l}\text { Max. TL } \\
(\mathrm{cm})\end{array}$ & $\begin{array}{l}\text { Dorsal } \\
\text { spines }\end{array}$ & $\begin{array}{l}\text { Dorsal } \\
\text { soft rays }\end{array}$ & $\begin{array}{c}\text { Anal } \\
\text { soft rays }\end{array}$ & $\begin{array}{l}\text { Pectoral } \\
\text { rays }\end{array}$ & $\begin{array}{l}\text { Pelvic } \\
\text { spines }\end{array}$ & $\begin{array}{c}\text { Pelvic } \\
\text { rays }\end{array}$ & $\begin{array}{l}\text { Caudal } \\
\text { rays }\end{array}$ & $\begin{array}{c}\text { Scales lateral } \\
\text { lines (UP; LO)* }\end{array}$ \\
\hline Notothenia sp. ${ }^{\dagger 1}$ & 16 & $4-6$ & $27-30$ & $22-25$ & $17-18$ & 1 & 5 & 14 & $52-56 ; 10-16$ \\
\hline Notothenia cf. angustata ${ }^{\dagger 2}$ & 13 & $3-6$ & 28 & $23-25$ & $18-19$ & & 6 & $15-16$ & $50-56 ; 14-16$ \\
\hline $\begin{array}{l}\text { Notothenia angustata/ } \\
\text { Paranotothenia angustata }\end{array}$ & 41 & $3-6$ & $28-36$ & $23-25$ & $17-19$ & $0-1$ & $5-6$ & $15-16$ & $50-56 ; 12-16$ \\
\hline $\begin{array}{l}\text { Notothenia magellanica/ } \\
\text { Paranotothenia magellanica/ } \\
\text { Notothenia macrocephala }\end{array}$ & 38 & $3-6$ & $28-31$ & $22-26$ & $16-18$ & & & & \\
\hline Notothenia microlepidota & 70 & $6-7$ & $27-28$ & $23-24$ & & & & & \\
\hline Notothenia microlepidota $^{\dagger 3}$ & 11 & $5-6$ & $27-31$ & $23-25$ & $17-19$ & & & & $57 ; 12$ \\
\hline Notothenia coriiceps & 62 & $4-6$ & $35-38$ & $26-30$ & $16-19$ & & & & $34-49 ; 6-17$ \\
\hline
\end{tabular}

"UP: upper lateral lines, LO: lower lateral line.

†uveniles, data from: ${ }^{\dagger}$ this study, ${ }^{2}$ Muñoz et al. (2001), ${ }^{3}$ Pequeño (1976)

${ }^{3}<$ https://folk.uio.no/ohammer/past/> 


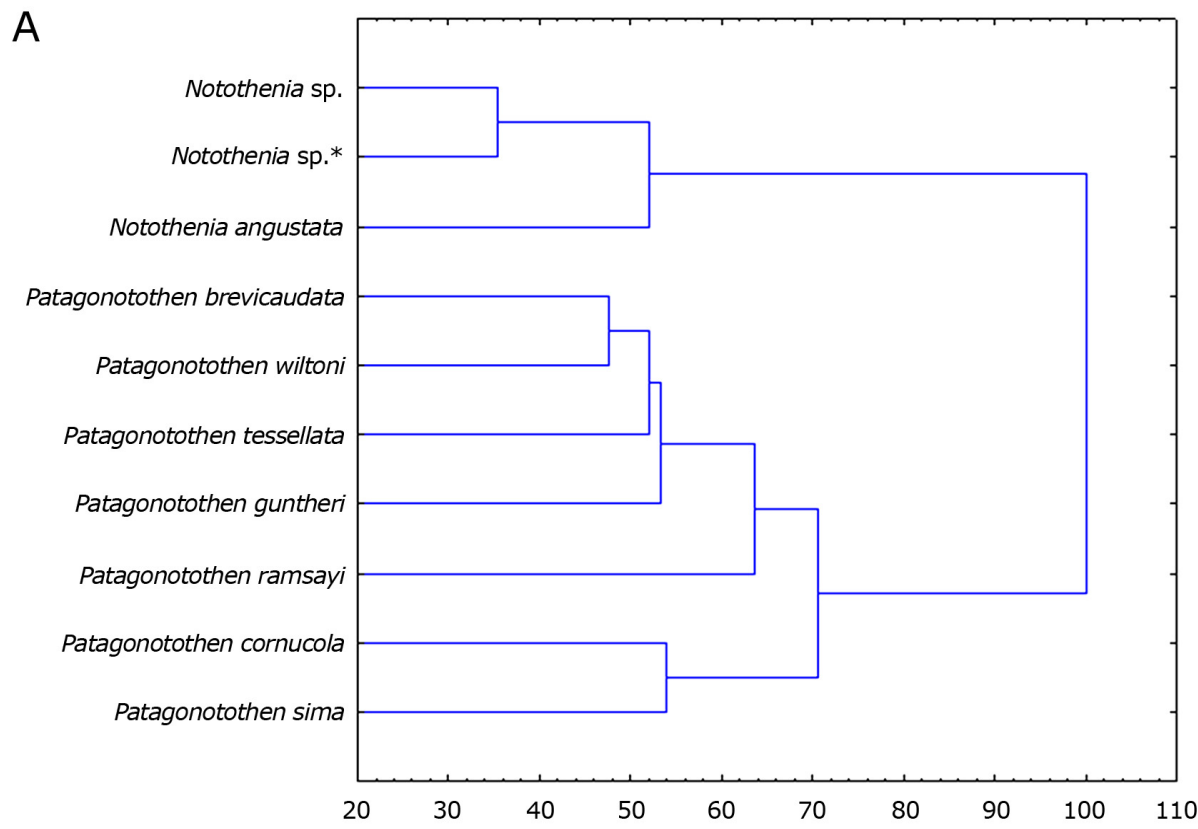

B

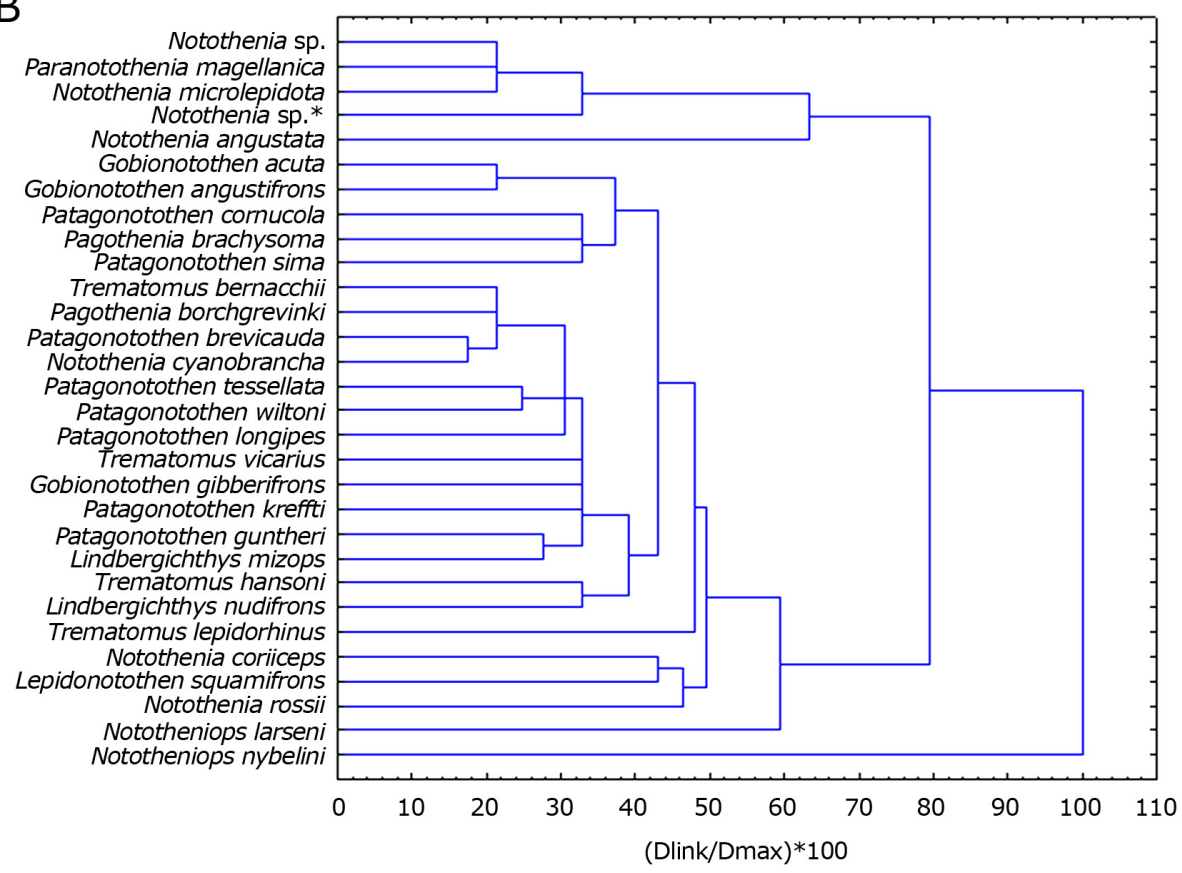

Figure 1. Conglomerate analysis according to the percentage of similarity based on meristic morphological variables of notothenid species. A) 13 variables in 10 fish species; B) $\mathbf{6}$ variables in $\mathbf{3 0}$ fish species. *specimens considered in Muñoz et al. (2001) identified as similar to $N$. angustata / Análisis de conglomerados según porcentaje de similitud en base a la morfología de variables merísticas de especies nototénidas. A) 13 variables en 10 especies de peces; B) 6 variables en 30 especies de peces. *especímenes considerados en Muñoz et al. (2001) identificados como similares a N. angustata 
The genetic results show that the three specimens of Notothenia sp. (from the present study) was closer to Notothenia coriiceps, with $94 \%$ of similarity and $89-98 \%$ of alignment, considering sequences of 14 specimens available in GenBank. Notothenia sp. was also closer with Paranotothenia magellanica, with $94 \%$ of similarity sequences but $88 \%$ alignment of one sequence available.

\section{COMPOSITION OF PARASITE COMMUNITY IN INTERTIDAL FISH}

Thirteen fish species were caught in the intertidal rocky zone of Lebu, with different sample sizes (Table 2); Notothenia sp. and Bovichthus chilensis were the most abundant. Ten fish species, with at least 5 specimens each, were considered for all statistical analyses.

Individual body sizes varied between 3.8 to $19.5 \mathrm{~cm}$ (total length); the smallest average was for clingfish $G$. marmoratus, and the largest was for S. sanguineus (Fig. 2A). Total weight varied from 0.7 to $113 \mathrm{~g}$, the smallest average was for $B$. chilensis and the largest was for $S$. sanguineus (Fig. 2B). Notothenia sp. averaged $9.2 \mathrm{~cm}$ in length, being one of the largest in the fish assembly. However, its average body weight was $12.7 \mathrm{~g}$, being within the medium range and similar to several other fish species (Fig. 2B).

Thirty parasitic taxa were found in the whole fish assemblage, most of the parasites identified at least to the family level (Table 3). Twelve fish species had parasites. There were clear differences in the richness and abundance of parasites between fish species. Most of the fish had between one and 6 parasite taxa. However, Notothenia sp. harbored the greatest richness, with 21 taxa, followed by $C$. geniguttatus with 9 taxa (Table 3). Total prevalence and the average abundance of parasites

Table 2. Intertidal fish species and their sample sizes ( $\mathrm{n}$ ) obtained from Lebu, south-central Chile. Parasitological data, such as the component community richness, total prevalence, and average abundance of the infracommunity ( \pm standard deviation, DE) are shown for each fish species. Different superscript letters (in prevalence and abundance) indicate significant differences among fish species / Especies de peces intermareales, con sus respectivos tamaños muestrales ( $n$ ), obtenidos en la zona de Lebu, centro-sur de Chile. Para cada una de ellas se muestran algunos datos parasitológicos, tales como la riqueza de la comunidad componente, la prevalencia total y la abundancia infracomunitaria promedio ( \pm desviación estándar, DE). Letras distintas en superíndices (en prevalencia y en abundancia promedio de parásitos) indican diferencias significativas entre especies de peces

\begin{tabular}{|c|c|c|c|c|c|c|}
\hline \multirow{2}{*}{ Fish Family } & \multirow{2}{*}{ Fish species } & \multirow{2}{*}{$\begin{array}{l}\text { Fish species } \\
\text { abbreviation* }\end{array}$} & \multicolumn{4}{|c|}{ Parasitological descriptor } \\
\hline & & & $\mathrm{n}$ & Richness & Prevalence & Abundance $\pm \mathrm{DE}$ \\
\hline Nototheniidae & Notothenia sp. & Noto & 95 & 21 & $90.5^{\mathrm{a}}$ & $8.62 \pm 6.56^{\mathrm{a}}$ \\
\hline \multirow[t]{2}{*}{ Labrisomidae } & Calliclinus geniguttatus & Cgen & 38 & 9 & $36.8^{\mathrm{b}}$ & $1.24 \pm 2.38^{\mathrm{c}}$ \\
\hline & Auchenionchus variolosus & Avar & 3 & 0 & 0.0 & $0.00 \pm 0.00$ \\
\hline Bovichthidae & Bovichthus chilensis & Bchi & 103 & 6 & $12.6^{\mathrm{b}}$ & $0.26 \pm 0.84^{\mathrm{c}}$ \\
\hline \multirow[t]{2}{*}{ Gobiesocidae } & Sicyases sanguineus & Ssan & 19 & 4 & $78.9^{\mathrm{a}}$ & $2.63 \pm 2.75^{\mathrm{a} . \mathrm{c}}$ \\
\hline & Gobiesox marmoratus & Gmar & 29 & 1 & $10.3^{\mathrm{b}}$ & $1.00 \pm 0.83^{\mathrm{c}}$ \\
\hline Eleginopsidae & Eleginops maclovinus & & 2 & 5 & 100.0 & $3.00 \pm 1.40$ \\
\hline \multirow[t]{2}{*}{ Clinidae } & Myxodes cristatus & Mcri & 7 & 3 & $42.9^{\mathrm{a}, \mathrm{b}}$ & $0.43 \pm 0.53^{\mathrm{c}}$ \\
\hline & Myxodes viridis & Mvir & 17 & 2 & $11.8^{\mathrm{b}}$ & $0.18 \pm 0.53^{\mathrm{c}}$ \\
\hline Gobiidae & Ophiogobius jenynsi & Ojen & 5 & 1 & $40.0^{\mathrm{b}}$ & $0.40 \pm 0.55^{\mathrm{c}}$ \\
\hline \multirow[t]{2}{*}{ Blenniidae } & Scartichthys viridis & Svir & 42 & 1 & $2.4^{\mathrm{b}}$ & $0.02 \pm 0.15^{\mathrm{c}, \mathrm{d}}$ \\
\hline & Hypsoblennius sordidus & Hsor & 27 & 3 & $11.1^{\mathrm{b}}$ & $0.15 \pm 0.46^{\mathrm{c}}$ \\
\hline Aplodactylidae & Aplodactylus punctatus & & 1 & 0 & 0.0 & $0.00 \pm 0.00$ \\
\hline
\end{tabular}

*Abbreviated names are used in other results (Table 4 and Fig. 4) 


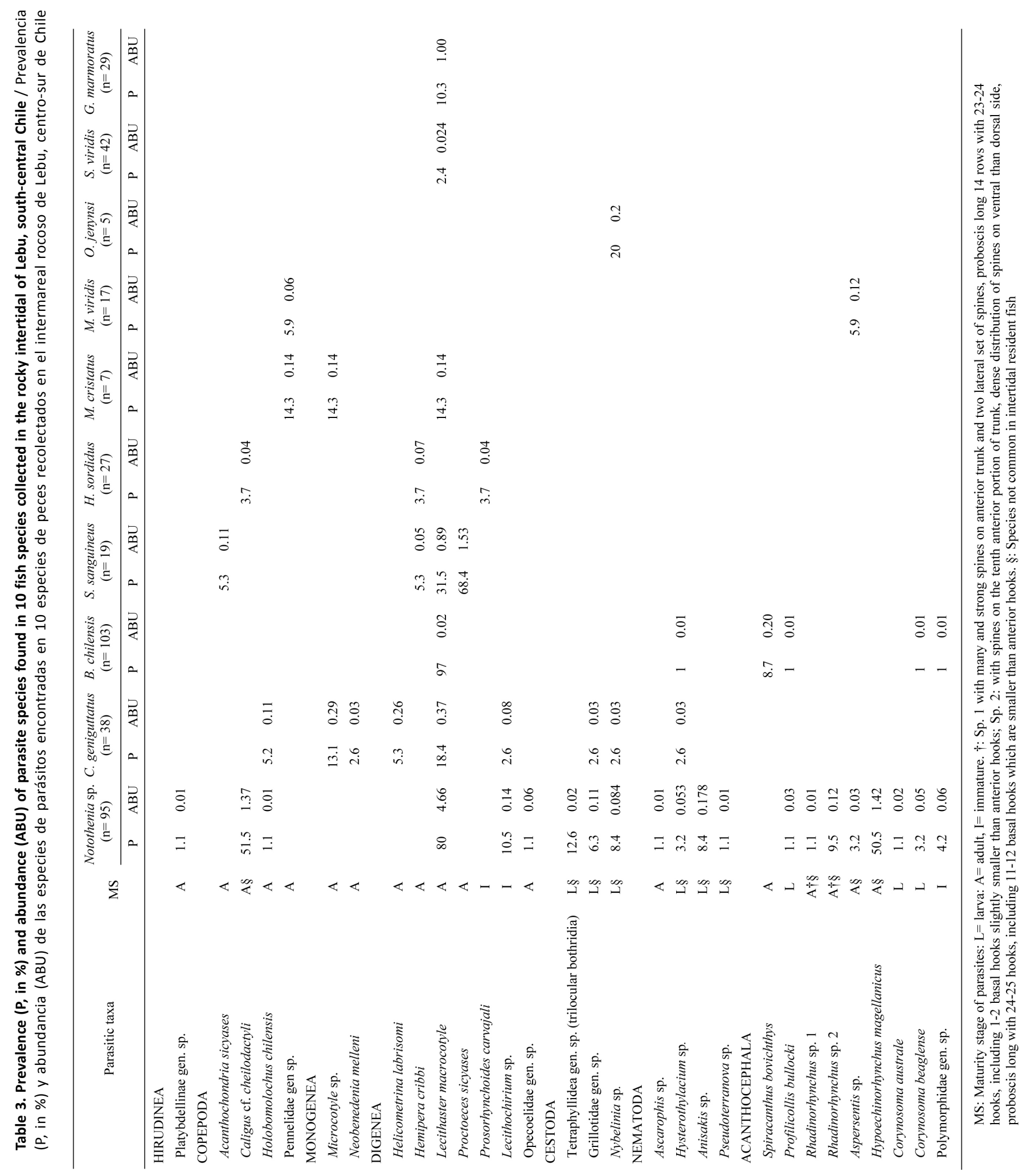



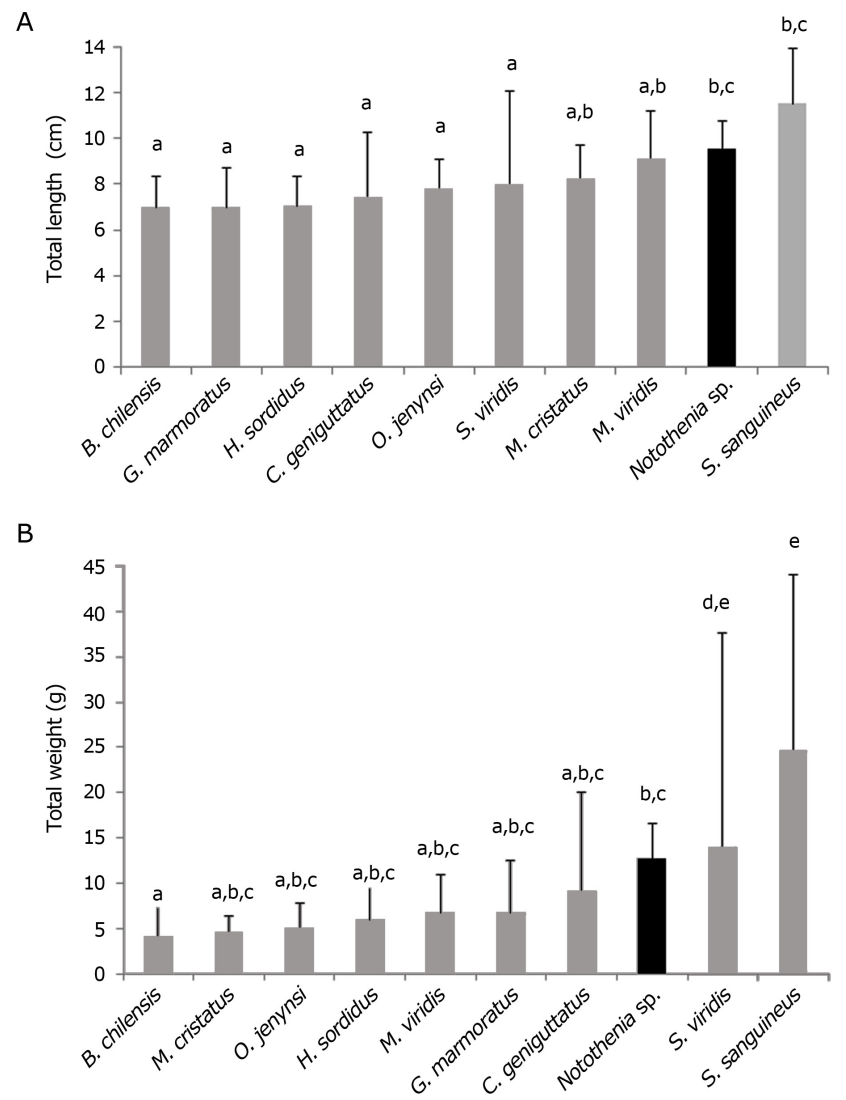

\begin{abstract}
Figure 2. Averages of body sizes, A) total length and B) weight of each fish species obtained from Lebu, south-central Chile and organized from lowest to highest fish size. Different letters on the bars indicate significant differences in body sizes among species / Promedios de los tamaños corporales, A) longitud total y B) peso de cada especie de pez obtenidos de Lebu, centro-sur de Chile y organizadas de menor a mayor tamaño. Letras distintas sobre las barras indican diferencias significativas en tamaños corporales entre especies
\end{abstract}

were also highest in Notothenia sp. (Table 2). The parasite descriptors were not significantly related to fish body weight $(P>0.2)$ (Fig. 3). Although parasite prevalence tends to increase with fish weight, this correlation was not significant (Fig. 3).

The parasite community composition was also different between fish species; $16(53.3 \%)$ out of the 30 parasite taxa found in total were only present in one host species; 10 taxa (33\%) were in 2 host species, 3 taxa were present in 3 fish species, and only one parasite species (the digenean Lecitasther macrocotyle) parasitized 7 host species (Table 3). Nine parasite taxa of Notothenia sp. were also found in other fish species (Table 4). Consequently, the Jaccard similarity index was low, with a maximum of $33 \%$ for most pairs of host species, and high (100\%) only for G. marmoratus and S. viridis, which were only parasitized by the digenean $L$. macrocotyle
(Tables 3 and 4). In the NMDS diagram, few fish species were close to each other (except G. marmoratus and $S$. viridis) and several others were distant according to their parasite taxa (Fig. 4), that was supported by the ANOSIM results $(\mathrm{R}=0.63 ; P=0.001)$. However, the parasitic similarity among fishes showed in the NMDS had a stress value of 0.36 (Fig. 2; Stress $=0.06$ ) suggesting a poor ordination fit (Clarke \& Warwick 1994).

In addition to the high parasite richness of Notothenia sp., 2 parasite taxa stand out for their high prevalence and abundance: the copepod Caligus cf. cheilodactyli and the acanthocephalan Hypoechinorhynchus magellanicus, but also the presence of other parasites, such as Rhadinorhynchus spp., Anisakis sp. and several cestodes, are normally not present in intertidal resident fish, whereas Lecithaster macrocotyle is prevalent and abundant in several fish species (Table 3). 

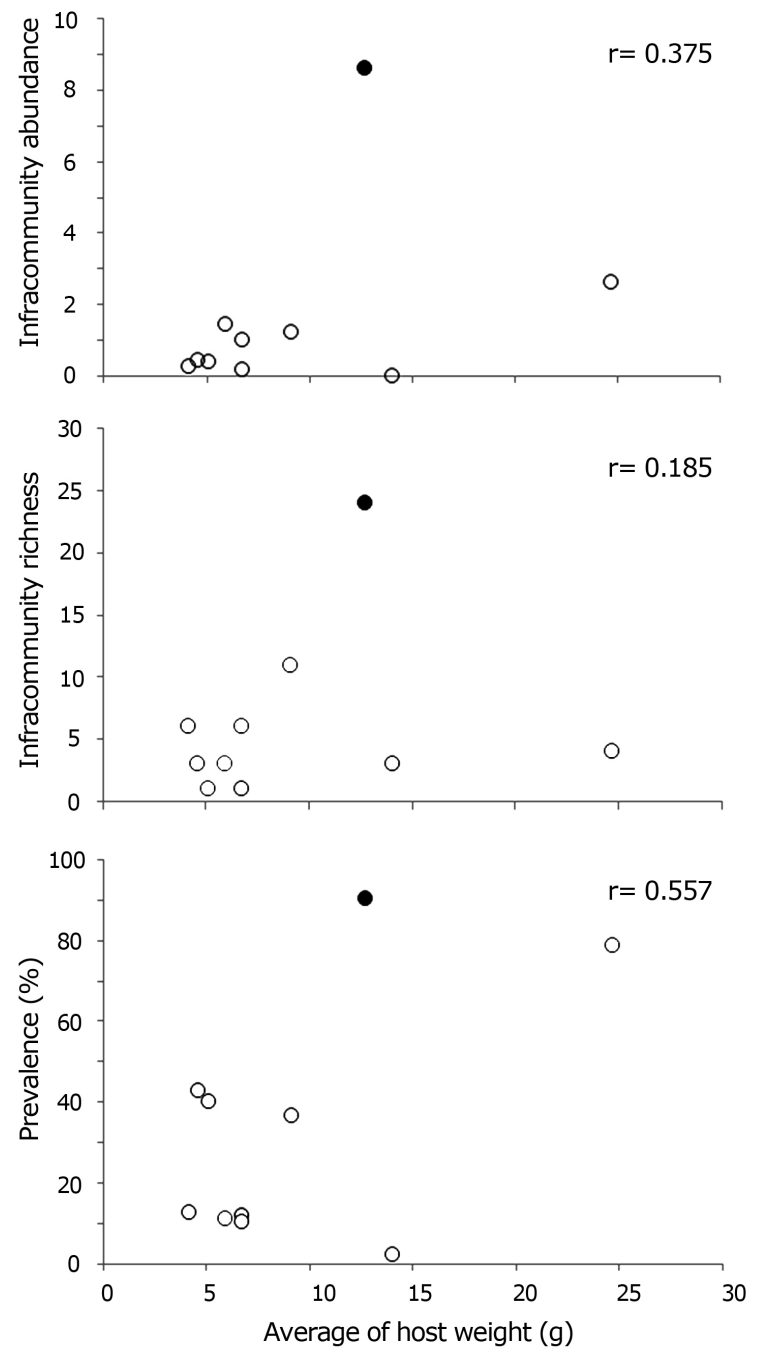

Figure 3. Mean abundance and infracommunity parasite richness and total prevalence of parasites related to host body weight of several species. The black dot on each graph indicates the position of Notothenia sp. $r=$ Pearson correlation / Promedio de abundancia y riqueza infracomunitaria de parásitos y prevalencia total de parásitos en relación al peso corporal promedio de varias especies de peces. El punto negro en cada gráfico indica la posición de Notothenia sp. $r=$ correlación de Pearson

\section{Discussion}

\section{IDENTIFICATION OF THE NOTOTHEN FISH}

The identification of Notothenia sp. from the intertidal of the central-south of Chile remains unclear. On the one hand, the specimens belong to the genus Notothenia because hypural 3 and 4 are completely fused (Fischer \& Hureau 1985). On the other hand, Notothenia sp. has a morphological affinity with Notothenia angustata.
Table 4. Matrix of similarity on parasitological data, using the Jaccard index, between pairs of intertidal fish species of Lebu. Fish names are abbreviated as in Table $\mathbf{2}$ / Matriz de similitud basada en los datos parasitológicos, mediante el índice de Jaccard, entre pares de especies de peces intermareales de Lebu. Nombre de peces están abreviados como en Tabla 2

\begin{tabular}{lcccccccccc}
\hline & Noto & Cgen & B chi & Ssan & Hsor & M cri & Mvir & Ojen & Svir & Gmar \\
\hline Noto & - & 0.272 & 0.227 & 0.045 & 0.045 & 0 & 0 & 0.045 & 0 & 0.045 \\
Cgen & - & 0.153 & 0.083 & 0 & 0.2 & 0 & 0.111 & 0.111 & 0.111 \\
Bchi & & - & 0.111 & 0 & 0.125 & 0 & 0 & 0.111 & 0.166 \\
Ssan & & & - & 0.2 & 0.166 & 0 & 0 & 0.25 & 0.25 \\
Hsor & & & & - & 0 & 0 & 0 & 0 & 0 \\
Mcri & & & & & - & 0.333 & 0 & 0.333 & 0.333 \\
Mvir & & & & & & - & 0 & 0 & 0 \\
Ojen & & & & & & & - & 0 & 0 \\
Svir & & & & & & & & - & 1 \\
Gmar & & & & & & & & & - \\
\hline
\end{tabular}

However, the latter has been considered as Paranotothenia due to the distribution of its hypural bones (hypural 3 and 4 are partially fused). The specimens of this study were also similar to $N$. microlepidota, for which meristic data were from intertidal specimens of southern Chile (Pequeño 1976). Fischer \& Hureau (1985) considered that $N$. microlepidota, $N$. angustata, and $P$. magellanica are morphologically similar and also co-occur in the same areas, and that they belong to the genus Paranotothenia because of the conformation of the hypural bones. Recently, a study based on both molecular and morphological aspects of notothen fish indicated that Paranotothenia should be considered as Notothenia (Sanchez et al. 2007) because of their high genetic similarity. Therefore, the use of the distribution of hypural bones can be a distinctive character among species and not between genera.

In our molecular analysis of Notothenia sp., the maximum genetic similarity (94\%) was with $N$. coriiceps (which is Antartctic fish), but it was not concordant with the morphological analysis (Table 2). With the all information analyzed, it is not possible to determine with certainty the Notothenia species of the present study. This fish was morphologically similar to $N$. microlepidota recorded by Pequeño (1976) and $N$. cf. angustata used by Muñoz et al. (2001), all juveniles from the intertidal zone. These fishes formed one distant group from several other notothen species (Fig. 1); therefore, it is quite possible that this 'group of fish'may be one undescribed species. 


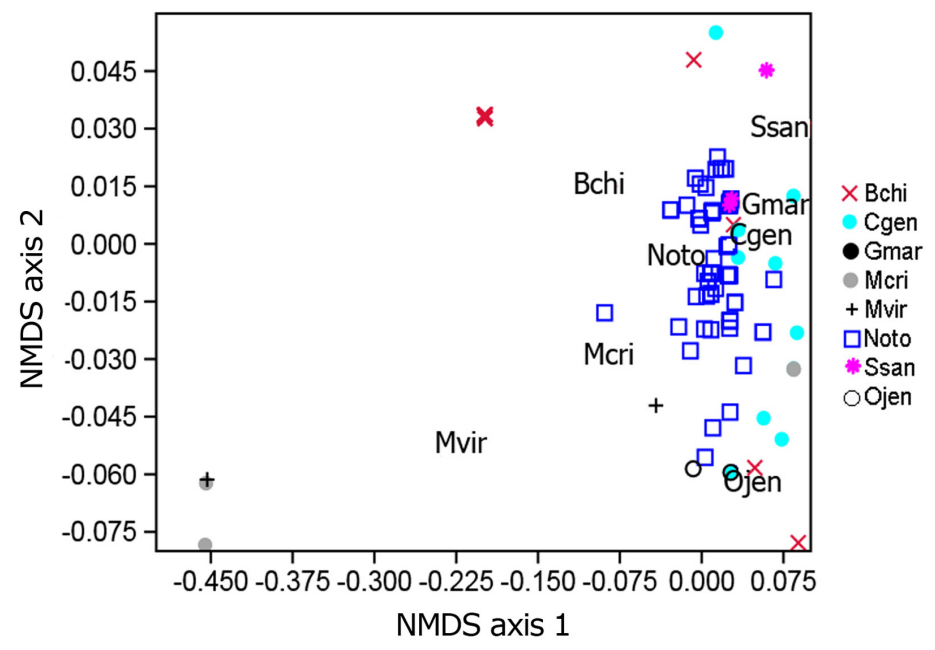

Figure 4. NMDS analysis of 10 host fish using the Jaccard similarity index based on the presence-absence of the parasite species. Fish names abbreviated as in Table 2 / Análisis NMDS en 10 peces hospederos, mediante el índice de similitud de Jaccard en base a la presenciaausencia de las especies parásitas. Nombre de peces abreviados como en la Tabla 2

\section{COMPOSITION OF PARASITE COMMUNITY IN INTERTIDAL FISH}

Of all fish species collected, Notothenia sp. had the greatest richness and abundance values at the level of parasite infracommunity. Moreover, Notothenia sp. hosted parasites that are not typical for intertidal fish, such as some anisakid nematodes, cestodes and acanthocephalans (Table 3). In addition to the high parasite richness, prevalence and average abundance of parasites was also high relative to other intertidal fish, which cannot be explained by the influence of body size - Notothenia sp. was a mediumsized fish (Fig. 2). The parasite fauna of this species was different, sharing no more than one-third of the parasite fauna with other fish species. There are three studies of parasite communities in Notothenia species, all of them related to $N$. coriiceps from the Antarctic zone (Szidat 1965, Palm et al. 1998, Zdzitowiecki \& Laskowski 2004), which contrast with the parasite community of Notothenia sp. of this study, sharing only 4.2 to $5.2 \%$ (Jaccard index) of their parasite species. Whereas other Antarctic fish, such as Trematomus spp. (Zdzitowiecki \& Ozouf-Costaz 2013), share between 14 and 23\% of the parasite species with Notothenia sp. Hence, juveniles of Notothenia sp. are different from intertidal fish and also from other notothens.

The low similarity of parasite composition between intertidal fishes has been recorded before, which is due to several parasites of intertidal fishes are highly hostspecific (Muñoz \& Cortes 2009). Moreover, a temporal fish that spend a short time in the intertidal zone, as
Notothenia sp., has low chance to become infected with parasites in that habitat. Consequently, a few generalist parasites could be acquired in the intertidal, such as the copepod Holobomolochus chilensis which has been recorded on several fish from the central coast of Chile (e.g., Muñoz \& Olmos 2007, Muñoz \& Delorme 2011, Muñoz \& Castro 2012), and the digenean Lecithaster macrocotyle that is a frequent parasite in several intertidal fish of central Chile (Soto et al. 2016), but it has also been found in different notothen species (Zdzitowiecki 1997), therefore, it is difficult to know if this digenean was acquired in the intertidal zone of central Chile.

Addressing how much of the parasitic fauna of Notothenia sp. is brought from another habitat, we found that several parasite taxa of Notothenia sp. are common in other environments (Table 3), for example, Tetraphyllidea, Anisakis, Pseudoterranova, and Rhadinorhynchus spp. are frequent parasites of subtidal fish, such as Aphos porosus, which are normally distributed from $5 \mathrm{~m}$ deep, and pelagic and demersal fish, e.g., Trachurus murphyi, Scomber japonicus, Merluccius spp., Genypterus spp., among others (Muñoz \& Olmos 2008), whose bathymetric distribution can exceed $50 \mathrm{~m}$. The copepod Caligus cf. cheilodactyli is common in subtidal fish, such as Cheilodactylus variegatus, Chromis crusma, Eleginops maclovinus, Odontesthes regia, Prolatilus jugularis, and Sebastes capensis, which live at depths comprised between 5 and $20 \mathrm{~m}$, but $C$. cheilodactyli has not been recorded in intertidal fish (Muñoz \& Olmos 2007). Moreover, the presence of the acanthocephalans 
Aspersentis sp. and Hypoechinorhynchus magellanicus is interesting because they are normally found in notothen fish from Antarctic and sub-Antarctic zones (Laskowski \& Zdzitowiecki 2017). Hypoechinorhynchus magellanicus has been also recorded in the benthopelagic fish Eleginops maclovinus (Sepúlveda et al. 2004), and in some intertidal fish although with low abundance and prevalence (Muñoz et al. 2002, Sepúlveda et al. 2004). Taken together, this information indicates that at least 11 parasite species of Notothenia sp. (nematodes, cestodes, acanthocephalans and a copepod) were acquired from a habitat other than the intertidal. Most notothen fishes are in Antarctic or Sub-Antarctic waters, mainly associated to the Cape Horn Current (DeWitt et al. 1990), but is also possible that Notothenia sp. is come from the Antarctic or sub-Antarctic zone and arrives, for a while, to the intertidal zone of central Chile for feeding, growing and surviving. Therefore, Notothenia sp. is one of the few notothen species that can reach northern distribution (up to $36^{\circ} \mathrm{S}$ ).

Within the intertidal temporal fish species, the behavior of Notothenia sp. is unusual. Several species arrive as a larval stage, settle, and remain for a time as juveniles, until they have grown sufficiently to migrate to the subtidal, such Kyphosidae (e.g., Girella laevifrons and Graus nigra) and Bovichthidae (Bovichthus chilensis), whereas other adult fish migrate from other habitats to the intertidal at a certain time of the year, to reproduce, as is the case of Aphos porosus. However, Notothenia sp. juveniles show a narrow range of body length, which corresponds to 104 to 126 days-old based on daily microincrements of the otoliths, determined in fish of 8 and $11 \mathrm{~cm}$ in length (Dr. Plaza, pers. comm.). This means that Notothenia sp. reaches the intertidal at an age of approximately 3 to 4 months-old. The narrow range of body lengths (between 8 and $14 \mathrm{~cm}$ in the whole sample) indicates that the stay in the intertidal zone is for only a short period of time. Instead, other fish, such as clingfish larvae (S. sanguineus and G. marmoratus), remain for 1 to 3 months in the plankton and settle in the intertidal with body lengths of $15-17 \mathrm{~mm}$ (corresponding to a recruiting age of 51 to 97 days) to become juveniles (Contreras et

${ }^{4}$ Dr. Guido Plaza, Pontificia Universidad Católica de Valparaíso, Valparaíso, Chile al. 2013). Similarly, S. viridis reach the intertidal zone after 30-45 days of larval development with a length of approximately $4 \mathrm{~cm}$ (Hernandez-Miranda \& Ojeda 2006). Therefore, Notothenia sp. was a large fish for its age, suggesting a faster grow rate compared to other fish of similar age from the intertidal zone.

In conclusion, Notothenia sp. has high parasite richness, especially if we consider that the specimens analyzed were very young. We suggest that the majority of its parasitic fauna was acquired in an environment different from the intertidal, possibly between the subtidal and demersal zone, but also from the Southern Chile where notothens are common. Only a few generalist parasite species could be acquired when living in the intertidal zone. This interesting fish species has not yet been well identified and little or nothing is known about its ecological aspects, except those shown in the present study.

\section{ACKNOWLEDGMENTS}

This study was supported by the FONDECYT Regular Grant 1130304 , and partially supported by the INACH Grant RT 32-16. We thank Dr. Guido Plaza, Escuela de Ciencias del Mar, Pontificia Universidad Católica de Valparaíso, Chile, for his help in determining fish ages. We also thank Pablo Conejeros and Melissa Rebolledo (Universidad de Valparaíso) for their assistance in molecular analysis.

\section{LITERATURE CITED}

Aguilera MA, N Valdivia \& BR Broitman. 2013. Spatial niche differentiation and coexistence at the edge: cooccurrence distribution patterns in Scurria limpets. Marine Biology Progress Series 483: 185-198.

Amin OM, RA Heckmann \& N Van Ha. 2011. Description of two new species of Rhadinorhynchus (Acanthocephala, Rhadinorhynchidae) from marine fish in Halong Bay, Vietnam, with a key to species. Acta Parasitologica 56(1): 67-77.

Berrios V \& M Vargas. 2004. Estructura trófica de la asociación de peces intermareales de la costa rocosa del norte de Chile. Revista de Biología Tropical 52: 201-212.

Brower JE \& JH Zar. 1977. Field and laboratory methods for general ecology, 194 pp. WC Brown Company Publishers, Iowa.

Bush AO, KD Lafferty, JM Lotz \& AW Shostak. 1997. Parasitology meets ecology on its own terms: Margolis et al. revisited. The Journal of Parasitology 83: 575-583. 
Chapman MG \& AJ Underwood. 1999. Ecological patterns in multivariate assemblages: information and interpretation of negative values of ANOSIM tests. Marine Ecology Progress Series 180: 257-265.

Clarke KR \& RM Warwick. 1994. Change in marine communities: An approach to statistical analysis and interpretation, 144 pp. Natural Environment Research Council, Bournemouth.

Contreras JE, MF Landaeta, G Plaza, FP Ojeda \& CA Bustos. 2013. The contrasting hatching patterns of larval growth of two sympatric clingfishes inferred by otolith microestructure analysis. Marine and Freshwater Research 64: 157-167.

De Vienne DM, G Aguileta \& S Ollier. 2011. Euclidean nature of phylogenetic distance matrices. Systematic Biology 60(6): 826-832.

DeWitt HH, PC Heemstra \& O Gon. 1990. Nototheniidae. In: Gon O \& PC Heemstra (eds). Fishes of the Southern Ocean, pp. 279-331, J. L. B. Smith Institute of Ichthyology, Grahamstown.

Díaz F \& M George-Nascimento. 2002. Estabilidad temporal de las infracomunidades de parásitos en la borrachilla Scartichthys viridis (Valenciennes, 1836) (Pisces: Blenniidae) en la costa central de Chile. Revista Chilena de Historia Natural 75: 641-649.

Eastman JT. 1991. Evolution and diversification of Antarctic notothenioid fishes. American Zoologist 31: 93-109.

Fischer W \& JC Hureau. 1985. Southern Ocean; CCAMLR Convention Area (Fishing Areas 48, 58 and 88) Volumen 2: 233-470. FAO Species Identification Sheets for Fisheries Purposes, Commission for the Conservation of Antarctic Marine Living Resources, Rome.

Flores K \& M George-Nascimento. 2009. Las infracomunidades de parásitos de dos especies de Scartichthys (Pisces: Blenniidae) en localidades cercanas del norte de Chile. Revista Chilena de Historia Natural 82: 63-71.

Folmer O, M Black, W Hoeh, R Lutz \& R Vrijenhoek. 1994. DNA primers for amplification of mitochondrial cytochrome $c$-oxidase subunit I from diverse metazoan invertebrates. Molecular Marine Biology and Biotechnology 3: 294-299.

Froese R \& D Pauly. 2017. Fishbase. <http://www.fishbase.org>

Hernandez-Miranda E \& FP Ojeda. 2006. Inter-annual variability in somatic growth rates and mortality of coastal fishes off central Chile: an ENSO driven process? Marine Biology 149: 925-936.

Laskowski Z \& K Zdzitowiecki. 2017. Acanthocephalans in Sub-Antarctic and Antarctic. In: Klimpel S, S Kuhn \& H Mehlhorn (eds). Biodiversity and evolution of parasitic life in the Southern Ocean, pp. 141-182. Springer International Publishing, Cham.
McMillan PJ, P Marriott, SM Hanchet, JM Fenaughty, E Mackay, H Sui \& F Wei. 2014. Fishes of the Ross Sea region. A field guide to common species caught in the longline fishery. New Zealand Aquatic Environment and Biodiversity Report 134: 1-54.

Muñoz G \& R Castro. 2012. Comunidades de parásitos eumetazoos de peces labrisómidos de Chile central. Revista de Biología Marina y Oceanografía 47: 565-571.

Muñoz G \& Y Cortés. 2009. Parasite communities of a fish assemblage from the intertidal rocky zone of central Chile: Similarity and host specificity between temporal and resident fish. Parasitology 136: 1291-1303.

Muñoz G \& N Delorme. 2011. Variaciones temporales de las comunidades de parásitos de peces intermareales de Chile central: hospedadores residentes vs temporales. Revista de Biología Marina y Oceanografía 43: 313-327.

Muñoz G \& V Olmos. 2007. Revisión bibliográfica de especies ectoparásitas y hospedadoras de sistemas acuáticos de Chile. Revista de Biología Marina y Oceanografía 42: 89-148.

Muñoz G \& V Olmos. 2008. Revisión bibliográfica de especies endoparásitas y hospedadoras de sistemas acuáticos de Chile. Revista de Biología Marina y Oceanografía 43: 173245.

Muñoz G, F Garcías, V Valdebenito \& M GeorgeNascimento. 2001. Parasitofauna y alimentación de Notothenia cf. angustata Hutton, 1875 (Pisces: Nototheniidae) en el intermareal de dos localidades del Golfo de Arauco, Chile. Boletín Chileno de Parasitología 56: 29-33.

Muñoz G, V Valdebenito \& M George-Nascimento. 2002. La dieta y la fauna de parásitos metazoos del torito Bovichthys chilensis Regan 1914 (Pisces: Bovichthydae) en la costa de Chile centro-sur: variaciones geográficas y ontogenéticas. Revista Chilena de Historia Natural 75: 661671.

Muñoz-Muga P \& G Muñoz. 2010. Comunidades de parásitos de Scartichthys viridis (Pisces: Blenniidae) de Chile central: localidad vs. longitud del hospedador. Revista de Biología Marina y Oceanografía 45: 165-169.

Navarrete AH, NA Lagos \& FP Ojeda. 2014. Latitudinal diversity patterns of Chilean coastal fishes: searching for causal processes. Revista Chilena de Historia Natural 87: $1-11$.

Norman JR. 1937. Coast fishes. Part II. The Patagonian Region. Discovery Report 16: 1-150.

Palm HW, N Reimann, M Spindler \& J Plotz. 1998. The role of the rock cod Notothenia coriiceps (Richardson, 1844) in the life-cycle of Antarctic parasites. Polar Biology 19: 399-406.

Pequeño G. 1976. Nuevos antecedentes sobre Notothenia microlepidota Hutton (Teleostomi, Nototheniidae). Museo Nacional de Historia Natural, Noticiario Mensual 241: 5-8. 
Pequeño G. 1984. Peces marinos comunes de Valdivia, 62 pp. Universidad Austral de Chile, Imprenta y Editorial Alborada, Valdivia.

Pequeño G \& J Lamilla. 1995. Comparación entre las ictiofaunas intermareales de los extremos austral y boreal de los canales patagónicos. Revista de Biología Marina 30: 155-177.

Petrochenko VI. 1971. Acanthocephala of domestic and wild animals, $478 \mathrm{pp}$. Academy of Science of the USSR. AllUnion Society of Helminthologist, Moscow.

Quijada P \& C Cáceres. 2000. Patrones de abundancia, composición trófica y distribución espacial del ensamble de peces intermareales de la zona centro-sur de Chile. Revista Chilena de Historia Natural 73: 739-747.

Reyes P \& M Hüne. 2012. Peces del Sur de Chile, 497 pp. Ocho Libros Editores, Santiago.

Sanchez S, AS Detta, C Bonillo, C Ozouf-Costaz, HW Detrich III \& G Lecointre. 2007. Molecular and morphological phylogenies of the Antarctic teleostean family Nototheniidae, with emphasis on the Trematominae. Polar Biology 20: 155-166.

Sepúlveda F, SL Marín \& J Carvajal. 2004. Metazoan parasites in wild fish and farmed salmon from aquaculture sites in southern Chile. Aquaculture 235: 89-100.

Shinen JL \& SA Navarrete. 2010. Coexistence and intertidal zonation of chthamalid barnacles along central Chile: Interference competition or a lottery for space? Journal of Experimental Marine Biology and Ecology 392: 176-187.
Soto J, G Muñoz, K González, FP Ojeda, M Castro \& M George-Nascimento. 2016. Interacciones parásitohospedero en peces del intermareal rocoso de la zona centro y centro-sur de Chile: comparación de la diversidad, conectancia y densidad de vínculos. Latin American Journal of Aquatic Research 44: 815-824.

Stepien CA, MT Dixon \& DM Hillis. 1993. Evolutionary relationships of the blennoid fish families, Clinidae, Labrisomidae and Chaenopsidae, congruence between DNA sequence and alloenzime data. Bulletin of Marine Science 52: 496-515.

Szidat L. 1965. Estudios sobre la fauna de parásitos de peces antárticos. I - Los parásitos de Notothenia neglecta Nybelin. Servicio de Hidrografía Naval, República de Argentina, 84 pp.

Williams J. 1990. Phylogenetic relationships and revision of the blenniid fish genus Scartichthys Smithsonian Contribution to Zoology 492: 1-30.

Zdzitowiecki K. 1997. Antarctic digenea parasite of fishes, 156 pp. Koeltz Scientific Books, Königstein.

Zdzitowiecki K \& Z Laskowski. 2004. Helminths of an Antarctic fish, Notothenia coriiceps, from the Vernadsky Station (Western Antarctica) in comparison with Admiralty Bay (South Shetland Islands). Helminthologia 41: 201-207.

Zdzitowiecki K \& C Ozouf-Costaz. 2013. Contribution to the knowledge of the parasitic fauna of fish off Adelie Land, Antarctica. Polish Polar Research 34(4): 429-435. 